\title{
Proletarianisation, Land, Income and Living Conditions of Farm Labourers in Kenya
}

\author{
DICK FOEKEN and NINA TELLEGEN
}

\begin{abstract}
In some areas in Sub-Saharan Africa, a rural proletariat has emerged, mainly consisting of labourers living and working on plantations and large mixed farms. Besides these 'full proletarians', there are also labourers living outside the agricultural estates who perform agricultural wage labour during specific seasons only. Most of these 'semi-proletarians' own a small piece of land. The study analyses the relationship between the degree of proletarianisation on the one hand, and the socio-economic situation and living conditions of labourers on large farms in Kenya's Trans Nzoia District on the other. In doing so, a comparison is also made with a group of nonlabourers. The conclusion is that a higher degree of proletarianisation coincides with a lower income level but not necessarily poorer living conditions.
\end{abstract}

\section{INTRODUCTION}

The rapidly increasing population in most rural areas of Sub-Saharan Africa causes a substantial and intensifying pressure on arable land. This situation is aggravated by the fact that in many areas land is divided among all sons of a deceased father. Both trends not only lead to a growing fragmentation of the land but also to increasing (near-)landlessness, particularly in the humid and sub-humid areas. Many landless people are forced to migrate to the towns and cities, in the hope of finding some kind of employment there. The result is a rapidly growing urban proletariat.

In most of the rural ${ }^{1}$ areas in Sub-Sahara Africa, agricultural wage labour is usually of a seasonal nature and is mostly confined to the periods of weeding and harvesting. Full-time agricultural wage employment is only found in areas with large agricultural estates, such as the plantations and

Dick Foeken and Nina Tellegen, African Studies Centre, PO dBox 9555, Leiden, The Netherlands. The authors wish to express their gratitude to Willem Veerman for his assistance with the data analysis, and to Henry Bernstein for his comments on an earlier draft

The Journal of Peasant Studies, Vol.24, No.4, July 1997, pp.296-313

PUBLISHED BY FRANK CASS, LONDON 
large mixed farms in Zimbabwe, Cameroon and Kenya. In these areas, a rural proletariat has come into existence. As a rule, either alone or with their families, these labourers live on the estate and are fully dependent on the farm owner, a dependency that embraces all aspects of life. They do not own any land and have only one means of (re)production at their disposal, namely their labour power. Even if they do have access to a small piece of land on the farm, the owner who 'gave' them the land can decide which crops they are allowed to grow and when they can plant or harvest. Other sources of income are often not accessible because these households are in most cases not allowed to perform income-generating activities elsewhere. Moreover, the provision of education, the supply of basic medical provisions, the possibility to obtain cash loans, etc. are all in the hands of the farm owner. There is, in the words of Clarke [1977: 51-2], a situation of 'total control of the employer over his workers'.

Besides these fully proletarianised estate workers, there is also a category of people that can be labelled as 'semi-proletarianised', that is, those workers who still have control over some means of (re)production [Standing, 1985], usually a small piece of land. The agricultural wage labour they perform is of a seasonal nature. They do not live on the estates; most of them have a small farm, where they grow food staples. Moreover, many also try to gain some income by means of self-employment in activities such as mat and basket making, beer brewing, tailoring, carpentry and all sorts of small-scale trading. Still, agricultural wage labour forms an essential element of these people's livelihood.

The question raised in this article is whether these differences in the degree of proletarianisation of workers are reflected in differences regarding socio-economic situation and living conditions. Studies carried out since the 1960 s indicate that plantation workers always had low living standards and that there has been very little improvement in their situation, still characterised by low wages, poor housing, poor sanitary and drinking water facilities, poor medical facilities and so on (for overviews, see for instance ILO, 1966 and Sajhau and von Muralt [1987]). Studies among plantation workers and workers on large mixed farms in Rhodesia (now Zimbabwe) also revealed that wages were low (even if payments in kind were included), that food consumption was very one-sided and unbalanced, that malnutrition among labourers' families was widespread and that bad health was very common [Chavunduka, 1972; Clarke, 1977). In Kenya, the working and living conditions of plantation workers had hardly changed during the twenty years after Independence (1963) and living conditions were generally 'deplorable' [Lugogo, 1986: 39]. Hence, it is no surprise that some authors argue that workers on large agricultural estates belong to the poorest segments of rural society [Shepherd, 1981; Davies, 1987]. 
These and other studies concerning labourers on large agricultural estates (mainly plantations) tend to deal with fully proletarianised labourers only. In many instances, such as in Kenya, there is also a category of workers performing labour on estates during specific seasons only and relying on other sources of income as well. Recent studies of incomegenerating activities of the rural population outside large estates pay considerable attention to self-employment activities (see, for example, Bryceson [1996]; Mead [1994]; Tellegen [1993]). As far as we know, studies in which different categories of labourers, living on and outside the agricultural estates respectively, are compared have never been carried out. In this article, which is based on a study conducted in Trans Nzoia District in Kenya in 1989 [Foeken and Tellegen, 1994), we make a comparison between different groups of labourers thought to be in different stages of proletarianisation. For simplicity's sake and for practical reasons, fully proletarianised labourers are operationalised as those living on the estates (the 'resident labourers') and semi-proletarianised labourers as those living outside the estates (the 'non-resident labourers').

The article starts with a brief description of Trans Nzoia District, followed by a section in which the major methodological aspects of the study are outlined. The next three sections contain the results of the study: first, labourers (as one aggregated group) are compared with a group who did not perform labour on a large farm (the non-labourers); then, labourers in different stages of proletarianisation are distinguished. Finally, some conclusions concerning the relationship between proletarianisation, access to land, income and living conditions are drawn.

\section{TRANS NZOIA DISTRICT}

Trans Nzoia District is located in north-western Kenya and has a surface of less than 2,500 square kilometres. Most of the district lies between 1,800 metres and 1,900 metres above sea level. The topography is generally flat with gentle undulations. Rainfall is fairly high, on average between 1,000 and 1,200 mm annually, and tends to be fairly reliable. Moreover, soils are generally rather fertile. Topography, rainfall distribution, temperature and soil characteristics make the district very suitable for maize growing and dairy farming, the two dominant agricultural activities in the District. Wheat, coffee and tea are cultivated in the higher areas.

During the colonial period, Trans Nzoia was part of the so-called 'White Highlands', that is the area designated as white settler land. Except for the district capital, Kitale, the whole district consisted of large farms. Since Independence, many of the large farms were bought by 'African' Kenyans, as individuals or groups of individuals. Some of these farms have been 
subdivided into smallholdings while others remained privately owned large farms (that is, farms of more than 50 acres, definition of the Kenyan Central Bureau of Statistics). The government also bought a number of farms and divided some to form settlement schemes but grouped others together, making them into very large enterprises. These large farms are run by the (parastatal) Agricultural Development Corporation (ADC). In 1989, the year of the study, there were nine of these ADC farms left. The result of these changes is the 'dualistic' nature of farm ownership in the district. On the one hand, large farms (both private and parastatal) occupying an estimated 60 per cent of the agricultural land area in the district; on the other hand, there are many smallholder farms, most of which have a size of five acres or less.

The large majority (over 90 per cent) of the large farms are mixed, combining the cultivation of maize (commercial maize and seed maize) and dairy farming, although one or more additional crops can be found on many farms, for example sunflowers, wheat, coffee, tea and pyrethrum. In terms of land use, dairy farming is the most important activity: on the farms that were part of the survey (see the Method section) almost 60 per cent of the land was used for grazing, most of it in the form of 'rough grazing', that is, on 'natural pastures'. Commercial maize and seed maize occupied almost 25 per cent, the other crops 10 per cent, while the remainder was for buildings and roads [Foeken and Verstrate, 1992].

Maize cultivation requires a lot of labour during the peak periods in the maize growing cycle (for weeding, top-dressing, detasseling and harvesting), the more so because the level of mechanisation is still low. Since the end of the 1980s prices for machinery, spare parts and inputs have increased strongly. As a consequence, the use of labour is often cheaper than that of machines. For many households, most of whom came as immigrants ${ }^{2}$ to the district, this type of labour is the only opportunity to obtain a monetary income (but obviously only for some months per year), since employment opportunities in Kitale - with a population of 56,218 in 1989 [Kenya, 1994b] the only centre of some size in the district - are relatively scarce. During the 1980 s there was even a decline in formal non-agricultural employment of 17 per cent in the town [Kenya, 1991a]. Another indication of the difficulties households in the district face in obtaining an income from non-agricultural wage labour is the fact that between 1970 and 1989 formal wage employment in the whole district increased by only 11 per cent, while the population increased by 200 per cent [Kenya, 1991a; 1994a].

With Ksh.7,784 per labourer in 1989, annual average earnings on mixed farms such as the ones in Trans Nzoia were rather low, compared with labourers on other types of estates [Kenya, 1991a]. Earnings of employees on coffee, tea and sugar plantations were 20 per cent, 40 per cent and 60 per cent higher, respectively. 
It is difficult to obtain a picture of the numbers of agricultural labourers employed in the district at the time of the survey. Based on our own data, an estimated 4,000 permanent labourers were employed on large farms of 100 acres and above. Compared with the 17,500 persons who were regularly employed in the agricultural sector in 1970 (Henkel, 1979), this indicates that formal employment on large farms has considerably declined during the 1970s and 1980s. As for the casual labourers, it is estimated that during the peak month of July (1989) between 17,000 and 20,000 persons found temporary employment on large farms of at least 100 acres (but in peak months many smaller farms employ casual labourers as well), of which about 40 per cent were actually living on those farms.

\section{METHOD}

Two surveys were held in 1989, a large-farm survey and a household survey. The large-farm survey consisted of 46 randomly selected farms from a frame of 219 eligible farms. ${ }^{3}$ The average farm size was 711 acres (284 hectares), the largest being 3,905 acres (1,562 hectares).

Data were gathered regarding farming activities and wage labourers. Information regarding the numbers of labourers and areas of recruitment allowed us to trace the households of labourers for the household survey. Both on- and off-farm selection was done by means of cluster sampling.

A group of non-labourers, defined as households in which nobody had performed any agricultural wage labour in the year preceding the survey, was selected as well. This selection was done by means of the 'nearest neighbour' method, that is, the nearest neighbour of a labourer living outside the large farms. For both labourers and non-labourers information was gathered regarding, amongst other things, household composition, economic activities of household members, farming, food consumption and nutritional condition. ${ }^{4}$

\section{RESULTS 1: LABOURERS VS. NON-LABOURERS}

In this section, a comparison is made between estate labourers and nonlabourers. The labourer group combines full and semi-proletarians, that is, the labourers living on and living outside the estates, respectively. The nonlabourers can be considered as non-proletarians: nearly all of them own a piece of farming land and many of them are engaged in some kind of selfemployment.

\section{Demographic Characteristics}

As far as household size and household composition were concerned, there were few differences between labourers and non-labourers. Although, on 


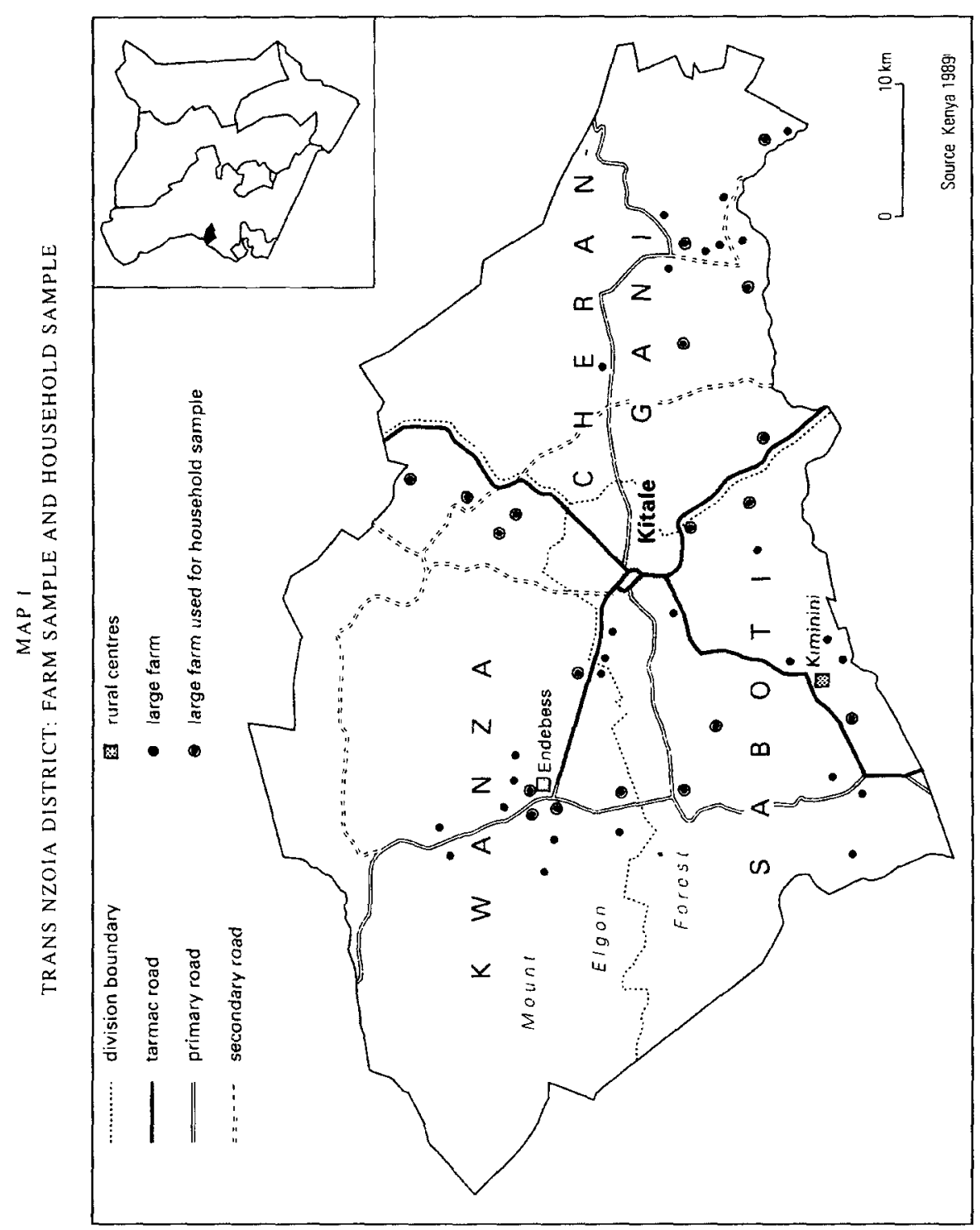


average, labourer households were smaller than non-labourer households (8.3 and 8.9 persons, respectively), and with younger household heads (57 per cent and 47 per cent younger than 40 years of age, respectively), these differences were not statistically significant. The same applied to the average numbers of children and adults.

Households headed by a woman were not very common: 11 per cent among labourers and not a single one among non-labourers. Female-headed households usually face problems in generating a reasonable monetary income because the female head is often the only adult in the household; hence, she can only be involved in the most accessible but least rewarding type of income generation: agricultural casual labour.

As far as the educational level of adult men and women is concerned, important differences emerged between the sexes and between the two groups. In both groups, more women than men never attended school, in particular among the labourers. In general, school enrolment was higher in the non-labourer households, while those who went to school did so for a longer period. This likely explains their not being involved in farm labour, since their schooling offers them opportunities for more rewarding jobs than farm labour, such as teaching, nursing, shop keeping, etc.

\section{Land and Income}

Table 1 presents some data regarding land and income. 'Land' refers to access to at least 0.1 acres of land, not to land ownership. Households with access to only a so-called kitchen garden around the homestead (about 0.05 acres) are considered landless. The table shows that one out of each five labourers had no access to land (for further details, see the section on Types

TABLE ]

LABOURERS AND NON-LABOURERS ' LAND AND INCOME'

\begin{tabular}{lcc}
\hline & $\begin{array}{c}\text { farm } \\
\text { labourers } \\
(\mathrm{N}=263)\end{array}$ & $\begin{array}{c}\text { non- } \\
\text { labourers } \\
(\mathrm{N}=35)\end{array}$ \\
\hline - \% landless households & 213 & 8.6 \\
- plot size (acres) & 1.7 & 3.9 \\
- total annual income $(\mathrm{Ksh} / \mathrm{hh})^{\mathrm{r}}$ & 10,678 & 21,714 \\
\hline
\end{tabular}

Notes: 1. The figures presented here show small deviations from figures presented in Foeken and Tellegen [1994], which is due to the method of calculation.

2. Only households with access to land. One case in the non-labourer group with 35 acres ts excluded here Plot size log converted ANOVA $(n=239) \mathrm{p}=000$

3. Total annual income log converted. ANOVA $(n=298) \mathrm{p}=0.00$

4 Total cash income log converted. ANOVA ( $n=294 ; 4$ households do not have any cash income) $\mathrm{p}=046$ 
of labourers). The three landless households in the non-labourer category concern cases where the head, and in some cases also the spouse, had some type of regular employment, such as teaching. Moreover, the households in the category with access to land had on average a much larger plot at their disposal than the labourers.

Total annual income includes the value of the household's own farm activities (crop cultivation and livestock production), the income from agricultural labour (on large farms) and the income from non-agricultural employment (non-agricultural wage labour and self-employment). ${ }^{5}$ The household's cash income consists of the latter two categories, plus the earnings from farm sales (crops, animals, milk). The figures presented in Table 1 suggest a relationship between income and plot size: total income of the non-labourer group is significantly higher than that of the labourer group. To quite a large extent, this is because a substantial part of higher total income in the non-labourer group expresses the value of households' own farming activities. A second source of the much higher incomes of non-labourer households is non-agricultural employment. ${ }^{6}$ When only households' cash incomes are considered, the differences between the two groups are smaller, which could be expected. What was not expected, however, was that the differences in cash income were not statistically significant, indicating that there is quite some variation within the two groups.

\section{Living Conditions}

'Living conditions' are defined in this article in a broad way and include various aspects of the quality of life: access to a latrine and improved drinking water, the number of household members per room (as a measure of the crowdedness of housing), the level of food consumption, and the nutritional condition of household members, in particular adult women and young children.

Most households have access to a latrine, although the percentage among non-labourers is significantly higher than among labourers (Table 2). Moreover, many households did not dispose of their own latrine, but had to share this facility with one or two other households.

Clean drinking water is another important determinant of the quality of life and a major factor in the health situation of the population. Trans Nzoia is a humid area and the survey showed that most households rely on surface water, because rivers, ponds, wells and small reservoirs are seldom dry. There appeared to be no difference between wet and dry seasons in this respect. Improved water sources, such as taps, were mainly found on the large farms, although certainly not on all farms.

Living densities, measured as the number of occupants per room, were 
more favourable among non-labourers, despite the larger households in this group. This reflects the fact that houses of these households contained on average more rooms than the houses of labourer households.

TABLE 2

LABOURERS AND NON-LABOURERS: LIVING CONDITIONS

\begin{tabular}{lcc}
\hline - \% with access to latrine & $\begin{array}{c}\text { farm } \\
\text { labourers } \\
(\mathrm{N}=263)\end{array}$ & $\begin{array}{c}\text { non- } \\
\text { labourers } \\
(\mathrm{N}=35)\end{array}$ \\
- \% with access to improved water source? & 75.7 & 97.1 \\
- no. of household members per room & 23.4 & 7.0 \\
- average energy intake (kcal/day/cu) & 4.2 & 2.9 \\
- adult women: average weight $(\mathrm{kg})^{4}$ & 2267 & 2581 \\
- children 6-59 months: \% wasted & 55.0 & 587 \\
- children 6-59 months: \% stunted & 10.3 & 1.6 \\
\hline
\end{tabular}

Notes: 1 Chi-2 test $(\mathrm{n}=298) \mathrm{p}=0.00$

2. Chi-2 test $(n=298) p=0.04$

3. ANOVA $(n=298) \mathrm{p}=0.00$

4. In kilo calories per consumer unit per day. A consumer unit is an adult equivalent based on energy requirements. For the calculation used here, see e.g. Foeken \& Tellegen 1994 , p. 105. Average energy intake log converted. ANOVA $(n=298) p=0.05$

5. N's are 292 and 38 , respectively. Average weight log converted. ANOVA $(n=330)$ $\mathrm{p}=0.01$

6. Wasted children are children with a weight-height ratio of less than 85 per cent of that of the reference group. Wasting is considered a sign of acute malnutrition. N's are 486 and 63, respectively. Chi- 2 test $(n=549) p=0.03$

7. Stunted children are children with a height-age ratio of less than 90 per cent of that of the reference group. Stunting is considered a sign of chronic malnutrition. N's are 486 and 63 , respectively. Chi- 2 test $(n=549) p=0.32$

The level of food consumption is expressed in terms of energy intake, that is, in kilo calories per consumer unit per day (data concern all food consumed on the day previous to the interview). Compared with a calculated energy requirement level of $2960 \mathrm{kcal}$ per consumer unit," Table 2 shows that the actual intake level was much lower in both groups. Further analysis revealed that only in about 20 per cent of labourer households were these requirements met, indicating a very problematic nutritional condition. The food consumption level among non-labourers was higher than among labourers, which seems to be in line with the income differences between the two groups.

The nutritional condition of adult women, expressed in terms of their average weight, reflects to a certain extent the energy intake levels of the households they belong to. The women in the non-labourer group were clearly heavier than those in the labourer group. The nutritional condition of 
young children between six months and five years of age - usually considered as the most vulnerable group in nutritional terms - is expressed in the percentages being wasted (too light for their length; an indication of acute malnutrition) and being stunted (too short for their age; an indication of chronic malnutrition). The percentage of wasted children in labourer households was high, certainly if compared with the national rural average recorded two years earlier (2.5 per cent; see Kenya [1991b]) or with the rural Trans Nzoia figure seven years earlier (2.8 per cent; see Kenya [1983]). The number of wasted children in the non-labourer group was significantly lower, and also compared favourably with the national and district figures. Stunting, however, was very common in both groups, the percentages being more or less comparable with the national figure of 1987 and the Trans Nzoia figure of 1982 (19.6 and 19.1 per cent, respectively). Even among non-labourers, one out of six children appeared to be stunted, indicating that this type of malnourishment is very common in the rural parts of Trans Nzoia.

In sum, it appears that in terms of land and income as well as living conditions, labourers can be considered disadvantaged compared with nonlabourers. Nevertheless, chronic malnutrition among children appeared to be common among both non-labourers and labourers.

\section{TYPES OF LABOURERS}

So far, labourer households have been treated as one group. However, as described in the Introduction, it is expected that differences exist between full proletarians and semi-proletarians, or put differently, between labourer households living on and off large farms. Moreover, it was hypothesised that these differences have consequences for the livelihoods of labourer households. Therefore, the group of labourer households is first divided into labourers resident on large farms and labourers living outside ("non-resident casuals'). Moreover, labourers living on farms are subdivided into permanent labourers and casual labourers ('resident casuals'). The reasoning behind this subdivision is as follows. 'Permanent labourers' earn a regular salary by doing farm labour, they live on the farm where they work, and they usually enjoy several kinds of facilities. The main difference with the 'resident casuals' is that the latters' employment is less regular even though they live on the farm as well - and paid less. Hence, one may expect that although both groups are considered fully proletarianised since they control only one means of (re)production (their labour power), permanent labourers will be better off than resident casuals. 'Non-resident casuals' are mostly smallholders living on a sub-divided farm in the vicinity of the large farm(s) where they work. Compared with resident casuals, their 
labour is more season-bound (so their income from casual labour is lower), they have fewer possibilities of sharing in the provisions that large farms offer to resident labourers, but, on the other hand, they have easier access to labour opportunities elsewhere.

\section{Permanent Labourers}

Permanent labourers - mainly herdsmen, dairy workers, farm workers, drivers, and watchmen - receive a monthly salary, which varies according to the type of work that is performed. It was conspicuous, however, that salaries for the same type of work showed quite some variation between the farms. According to information given by owners/managers of the large farms, average monthly wages for dairy workers and farm workers were 350 and 332 Kenyan shillings (Ksh.), respectively, in both cases lower than the legally fixed minimum wage at that time (Ksh.354). However, according to information collected among labourers themselves (during the household survey), average monthly salaries for farm workers and dairy workers was in the range of Ksh.250 to Ksh.270, considerably less than the figures given by the owners/managers and far (25-30 per cent) below the then legally fixed minimum.

On nearly all farms, permanent labourers were provided with a house, water supply, a latrine, basic medical services and a piece of land for their own use, but labourers were not totally free regarding the use of that land. On eight of the 21 farms with seed maize, labourers were not allowed to grow maize on their plots because of fields of seed maize nearby. It was generally forbidden to keep livestock. Many farms (70 per cent) offered labourers the opportunity to buy maize from the farm's stock for reduced prices, that is, on average about Ksh.35 per debe (about $15 \mathrm{~kg}$ ) instead of the normal market price of Ksh.45 at that time. On some farms ( 32 per cent), labourers were also able to buy milk at a relatively low price, that is, on average three shilling per litre instead of the normal market price of five. For rather obvious reasons (the number of cows), this provision was limited to larger farms. Finally, on most farms, permanent labourers received gifts in the form of food (not to be confused with payments in kind, which were uncommon). This usually consisted of meat, which was given at 35 farms (78 per cent), mostly at Christmas.

\section{Resident Casuals}

Although the number of casual labourers employed on the farms was clearly related to the maize cycle, a certain amount of work throughout the year is done by casual labourers. They are generally recruited from family members of permanent labourers (wives, older children) and some of the resident casuals. In general, resident casuals enjoyed the same benefits as 
the permanent labourers. On most farms ( 86 per cent) this included also a piece of land, be it often no more than a so-called kitchen garden. On farms where cheap maize was available for permanent labourers, resident casuals could benefit from that provision as well.

Again, a subdivision of two types of resident casuals can be made, notably so-called 'regular casuals' and squatters. The former have been recruited by employers on a more or less permanent basis, and usually live in the same labour camp as permanent labourers. They are not permanent labourers, however, because they are paid on a daily basis and only for the days they have been working. As a rule, these labourers are not allowed to perform labour outside the farm, on pain of being removed. Squatter households came 'by themselves' and usually live on the fringes of the farm, where they occupy small pieces of land. They do not face the same restriction regarding working elsewhere, but de facto their main source of income is the work they perform on the farm they live on.

\section{Non-Resident Casuals}

During peak labour periods, not only are all available resident casuals employed, but also a substantial number of non-resident casuals. Most of these are recruited from nearby former large farms that were subdivided into smallholder plots. Often, some small farmers in the neighbourhood act as a kind of broker or labour recruiter. The result is that the casual labour force of a particular large farm is mainly recruited from the same households over the years.

Compared with the two groups of resident labourers, non-resident casuals had less access to the facilities offered by the large farms. However, on about half of the farms they were able to buy cheap maize from the farm's stock, on a few farms cheap milk was available, while basic medical aid was provided on most farms as a standard facility.

The legal daily wage for unskilled casual labourers was Ksh.14/90 at the time of the survey. From the farms' administration concerning the casual labourers (both resident and non-resident), it was possible to calculate fairly accurately the average daily payment per labourer, which appeared to be Ksh.12/40. On most farms, casual labourers were paid below the legal level, the absolute minimum being Ksh. 8 per day.

\section{RESULTS $2 \cdot$ TYPES OF LABOURERS COMPARED}

\section{Demographic Characteristics}

Average household size of 7.4 persons of both permanent labourers and resident casuals was significantly $(\mathrm{p}<0.05)$ smaller than that of non-resident 
casuals ( 8.8 persons). Both the number of children and the number of adults in households residing on the farms were smaller $(\mathrm{p}<0.05)$. This can be explained by the younger 'age' of the resident households (for instance, household heads among resident casuals were significantly younger than those among non-resident casuals; $p<0.05$ ). The smaller number of adults in resident households can also be related to the limited labour opportunities for people living on large farms, and to the ban imposed on them from working outside the farms. Adult members of households residing on the farms have to migrate in order to obtain an income elsewhere.

Female-headed households were almost exclusively found among the non-resident casuals. In this group, one out of every seven households was headed by a woman. Female-headed households were rarely found on the large farms, as it is almost exclusively men who are employed by farm owners as permanent labourers or 'regular casuals'.

As for the educational level of the three groups, there appeared to be a significant difference $(\mathrm{p}<0.05)$ between non-resident casuals, on the one hand, and permanent labourers and resident casuals, on the other. On average, both males and females among the non-resident casuals had attended school about one year longer than the adults in the two other groups.

\section{Land and Income}

In Table 3, the three labourer categories are compared on two major economic indicators: land and income. Half of resident casual households were landless. These were the 'regular casuals' living in labour camps. The other half, the squatters, had access to on average about one acre of land for food production. Although the large majority of permanent labourers had access to a piece of land, average plot size was as small as that of the squatters. Moreover, the plots that resident labourers were able to cultivate belonged to the farms they lived on. Almost all non-resident casuals, however, owned their own plots, which were also significantly larger than those of resident labourers. Still, the average plot of non-resident casuals was too small to feed an average family of almost nine persons, which explains their involvement in farm labour.

The larger plots of non-resident casuals is reflected in their (significantly) higher total annual income, at least in comparison with resident casuals. If only cash income is considered, the differences between the three groups are no longer significant. Table 3 also shows what part of households' cash income was derived from wage employment on the large farms. As could be expected, this percentage was very high for the two groups of resident labourers. A few people in these groups (mainly squatters in the group of resident casuals) managed to realise a very small income 
TABLE 3

LAND AND INCOME BY LABOURER CATEGORY

\begin{tabular}{lrrr}
\hline & $\begin{array}{r}\text { permanent } \\
\text { labourers } \\
(\mathrm{N}=47)\end{array}$ & $\begin{array}{r}\text { resident } \\
\text { casuals } \\
(\mathrm{N}=5 \mathrm{I})\end{array}$ & $\begin{array}{c}\text { non-resident } \\
\text { casuals } \\
(\mathrm{N}=165)\end{array}$ \\
\hline - landless households & 19.1 & 49.0 & 13.3 \\
- plot size (acres) & 1.2 & 1.1 & 2.3 \\
- total annual income $(\mathrm{Ksh} / \mathrm{hh})^{2}$ & 9,625 & 6,950 & 12,131 \\
- total cash income $(\mathrm{Ksh} / \mathrm{hh})^{2}$ & 7,867 & 6,135 & 7,689 \\
- income from farm labour as \% of total cash income & 95 & 91 & 63 \\
\hline
\end{tabular}

Notes: 1 . Only households with access to land. Two households in the permanent labourers category owning a large plot outside the large farm (15 and 26 acres), as well as one household in the group of non-resident casuals with a plot of 30 acres, are excluded. Plot size $\log$ converted. ANOVA $\mathrm{p}=0.00$. Scheffe test differences are significant between permanent labourers and non-resident casuals and between resident casuals and non-resident casuals, not between permanent labourers and resident casuals.

2. Total annual income log converted. ANOVA $p=0.00$. Scheffe test difference significant $(p<0.05)$ between resident casuals and non-resident casuals. The other differences are not significant.

3. Total cash income log converted. ANOVA $p=0.423$.

from self-employment. Among non-resident casuals, dependence on agricultural wage labour, although still substantial, was smaller due to access to non-agricultural employment activities and/or income from farming activities. Further analysis revealed that there is indeed a significant correlation between share of cash income earned through farm labour, on the one hand, and total income and total cash income on the other. In other words, the extent to which households are dependent on farm labour strongly influences their income: higher dependency coincides with lower household income.

In order to interpret the absolute (gross) income levels of the five study groups, the figures are compared with the average (net) income of all rural households in Kenya in 1989 (that is, at the time of the survey), which was estimated at Ksh. $18,900 .{ }^{8}$ Even given that these income figures are no more than a fairly rough estimation, the three groups - and resident casual labourers in particular - can be considered as quite poor. In fact, it was only in the group of non-labourers (see Table 1) that average (gross) income exceeded the national average rural (net) income level.

\section{Living Conditions}

Differences between the three categories of labourers regarding the various aspects of the quality of life were smaller than expected. For instance, there were no significant differences regarding 'living density' (average number of persons per room), food consumption, nutritional condition of adult 
women and the percentage of wasted young children. Other variables, however, did show significant differences which are briefly discussed below.

Latrines were much more common among non-resident casuals than among labourer households residing on large farms. It was rather surprising that 43 per cent of permanent labourers did not have a latrine at their disposal, the more so as 90 per cent of farm owners/managers mentioned providing their permanent labourers with this facility. Apparently, living in a labour camp did not automatically imply sanitary facilities. Moreover, 40 per cent of those who did have access to a latrine shared it with one or more other households. The percentage of households with access to a latrine was much higher among those living outside the large farms ( 84 per cent). However, also among these households, about 30 per cent shared a latrine with one or two neighbours.

The earlier observation that improved drinking water sources are mainly found on large farms was confirmed. About half of the resident labourers had access to taps, one of the more common facilities in the labour camps. Of non-resident labourers, only ten per cent had access to an improved water source.

As mentioned above, despite the significant differences concerning total household income between resident and non-resident casuals, differences regarding level of food consumption (measured in terms of energy intake) and nutritional condition of the adult women and young children were rather small. But there is one exception. It was shown that stunting was very common among the labourers' children (Table 2). This applied particularly to resident casuals (29.3 per cent) and non-resident casuals ( 24.8 per cent). The percentage of stunted children among permanent labourers, however, was surprisingly low ( 10.6 per cent), the differences with the two categories of casual labourers being statistically significant $(p<0.05)$. We have no ready explanation for this phenomenon. In-depth analysis showed that these children were already relatively tall at birth (better care for the mothers during pregnancy?), but also that while growing they lost most of this initial lead.

\section{CONCLUSION}

Rural households in Trans Nzoia find themselves in a difficult position. The relatively small farms they have and lack of formal employment possibilities, plus low average educational levels, suggest that most of these households have only two options: migrating to a place with better opportunities or looking for work on one of the many large farms. Since many choose the latter option, wages on these farms are very low. 
The questions raised in this paper are whether farm labourers in general are worse off than non-labourers, and whether more proletarianised labourers are worse off than other labourers. The first question could be answered in the affirmative: aggregated as one group, the three categories of labourers are disadvantaged relative to non-labourers. In terms of land and income as well as living conditions, nearly all variables showed a significant difference in favour of non-labourers.

As for the second question, the situation was more complex. The incomes generated by full proletarians were lower and the plots they had were smaller. However, this did not in all respects imply worse living conditions as well. Energy intake did not significantly differ between the various groups, neither did the nutritional condition of women and the percentage of wasted children, while the percentage of stunted children was even lowest among one of the fully proletarianised sub-groups: the permanent labourers. This lack of a clear relationship between household income on the one hand, and nutritional condition on the other, was found in another Kenyan study as well [Hoorweg, Foeken and Klaver, 1995].

In the mid-1980s, Lugogo [1986] observed that due to the increasing use of labour saving techniques, employment in the estate sector stagnated and its composition was changing towards relatively less permanent labourers and more casual labourers. Indeed, during fieldwork in 1989, we were aware of at least one farm where all permanent labourers had recently been turned into 'resident casuals'. Together with the fact that the supply of labour will continue to exceed demand for a long time to come and that until now the union which represents farm workers has been unable to exert much influence [Leitner, 1976; Lugogo, 1986], it is to be feared that the prospects for a better future for estate labourers are fairly grim.

\section{NOTES}

1. Rural is defined here in the strict sense, that is, the farming areas

2. Of the household heads included in the survey, 70 per cent were born outside Trans Nzoia District. The large majority of these came from neighbouring districts like Bungoma, Kakamega and Turkana. See Foeken and Tellegen [1994: Section 6.1].

3. Eligible farms were those with a minimum size of 100 acres, instead of the CBS cut-off point of 50 acres, the reason being that farms between 50 and 100 acres appeared to employ hardly any permanent labourers.

4. For more detailed information regarding the methodology of the study, see Foeken and Tellegen [1994: Ch.3].

5. These are gross incomes, since no data are available regarding input costs for agriculture and self-employment activities.

6. Non-agricultural employment consists of non-agricultural wage labour and self-employment. It is a widespread phenomenon in rural Sub-Saharan Africa that part or even all of this income is earned by people who have migrated. Among the labourer households in Trans Nzoia District, it was found that one-quarter of the persons engaged in this type of income- 
generating activity could be labelled as 'non-residents', that is, with a visiting frequency of once a month or less. For those with a permanent job, this applied to 35 per cent.

7. Based on WHO/FAO/UNU, 1985: 133. This level corresponds to about $2,000 \mathrm{kcal}$ per capita.

8. The income data are derived from the Rural Household Budget Survey 1981/82 (see Kenya [1988]). This includes income in both cash and kind, the latter being mainly the value of home-produced food. It is not clear how the value of home-produced food has been calculated, that is, either in terms of the market value or in terms of the value of seed and fertiliser. In order to obtain the income in 1989 prices, the income of the 1981/82 figure (Ksh.9,948) was multiplied by 1.9 (Ksh.18,900), being the ratio between the lower income index of consumer prices in Nairobi in July 1989 and that of 1981/82 (see Kenya [1990a; 1986a].

\section{REFERENCES}

Adams, J., 1991, 'The Rural Labour Market in Zimbabwe', Development and Change, Vol.22, No.2, pp.297-320.

Bryceson, D.F., 1996, 'Deagrarianization and Rural Employment in Sub-Saharan Africa: A Sectoral Perspective', World Development, Vol.24, No.1, pp.97-111.

Chavunduka, G., 1972, Farm Labourers in Rhodesia. Rhodesian Journal of Economics, Vol.6, No.4, pp. $18-25$.

Clarke, D., 1977, Agricultural and Plantation Workers in Rhodesia, Gwello: Mambo Press.

Davies, S., 1987, 'Plantations and the Rural Economy: Poverty, Employment and Food Security in Kenya', IDS Bulletin, Vol.18, No.2, pp.15-20.

Foeken, D. and N. Tellegen, 1994, Tied to the land. Living conditions of labourers on large farms in Trans Nzoia District, Kenya, Aldershot: Avebury.

Foeken, D. and L. Verstrate, 1992, Labour Conditions on Large Farms in Trans Nzoia District. Kenya, Nairobi/Leiden: Ministry of Planning and National Development/African Studies Centre, Food and Nutrition Studies Programme, Report No.43.

Henkel, R. (1979), Central places in Western Kenya: A Comparative Regional Study Using Quantitative Methods, Heidelberg: University of Heidelberg.

Hoorweg, J., Foeken, D. and W. Klaver, 1995, Seasons and Nutrition at the Kenya Coast, Aldershot: Avebury.

ILO, 1966, Plantation Workers: Conditions of Work and Standards of Living, Geneva: International Labour Office.

Kenya, Republic of, 1983, Third Rural Child Nutrition Survey. Nairobi: Ministry of Finance and Planning, Central Bureau of Statistics.

Kenya, Republic of, 1986, Statistical Abstract 1986, Nairobi: Ministry of Planning and National Development, Central Bureau of Statistics.

Kenya, Republic of, 1988, Economic Survey 1988, Nairobi: Ministry of Planning and National Development, Central Bureau of Statistics.

Kenya, Republic of, 1989, Trans Nzola District Development Plan 1989-93, Nairobi: Ministry of Plaming and National Development.

Kenya, Republic of, 1990, Statistical Abstract 1990, Nairobi: Ministry of Planning and National Development, Central Bureau of Statistics.

Kenya, Republic of, 1991a, Statistical Abstract 1991, Na1robi: Ministry of Planning and National Development, Central Bureau of Statistics.

Kenya, Republic of, 1991 b, Fourth Rural Child Nutriton Survey, Nairobi: Ministry of Planning and National Development, Central Bureau of Statistics.

Kenya, Republic of, 1994a, Kenya Population Census 1989, Volume 1, Nairobi: Office of the Vice-President/Ministry of Planning and National Development, Central Bureau of Statistics

Kenya, Republic of, 1994b, Kenya Populaton Census 1989, Volume 2, Nairobi: Office of the Vice-President/Ministry of Planning and National Development, Central Bureau of Statistics.

Leitner, K., 1976, 'The Situation of Agricultural Workers in Kenya', Revtew of African Polttcal 
Economy, No.6, pp.34-50.

Lugogo, J.A., 1986, 'The Impact of Structural Changes in Kenya's Plantation Sector', in ILO, The Socio-economic Implications of Structural Changes in Plantations in African Countries, Geneva: International Labour Office.

Mead, D.C., 1994, 'The Contribution of Small Enterprises to Employment Growth in Southern and Eastern Africa', World Development, Vol.22, No.12, pp.1881-94.

Niemeijer, R., Foeken, D. and W. Klaver, 1991, Seasonality in the Coastal Lowlands of Kenya, Part 4/5: Food Consumption and Anthropometry, Nairobi/Leiden: Munistry of Planning and National Developmenv/African Studies Centre, Food and Nutrition Studies Programme, Report No.38.

Sajhau, J.-P. and J. von Muralt, 1987, Plantations and Plantation Workers, Geneva: International Labour Office.

Shepherd, A.W., 1981, 'Capitalist Agriculture in Africa', African Development, Vol.6, No.3, pp.5-21.

Standing, G. (ed.), 1985, Circulation and the Labour Process, London: Croom Helm.

Tellegen, N., 1993, Rural Employment in Sub-Saharan Africa: A Bibliography, Leiden: AfrikaStudiecentrum, Working Paper No.18.

WHO/FAO/UNU, 1985, Energy and Protein Requirements, Geneva: World Health Organisation, Technical Report 724. 


\title{
Colonial Sedentarisation and Subjugation: The Case of the Banjaras of Berar 1850-1900
}

\author{
LAXMAN D. SATYA
}

The Banjaras were a mobile community of central India. Portage of goods and services was their primary occupation. This brought them in contact with a whole spectrum of population from the plains to the hills. It also generated tremendous diversity within the Banjara society in terms of language, customs, beliefs and practices. It developed in them a rather casual, unorthodox and open attitude towards religion, family, and women. Many of the practices which were prohibited in the mainstream orthodox Hindu and Muslim society were freely practised in the Banjara Community. Practices such as courtship and pre-marital sex; late marriage; widow re-marriage and so on, were common social practices much to the suspicion of religious orthodoxy and the colonial state. Since the colonial state was ever suspicious and fearful of the moving people, the Banjaras became the target of colonial wrath. The main aim of the colonial state was to coerce the Banjaras to sedentirise into settled agriculture. The entire colonial police, bureaucracy and legal institution was organized to monitor and force the Banjaras to abandon their traditional lifestyle. This resulted not only in their cultural loss but also in their demographic decline. The Banjaras became the worst victims of colonial persecution and oppression. The famine cycle of $1890 \mathrm{~s}$ hit the Banjaras the hardest. Even the mainstream Hindu and Muslim orthodoxy joined the colonial state in Banjara persecution. But the Banjaras struggled and resisted all attempts to exterminate their society and culture.

The Banjaras were the carriers of goods and services in the Deccan plateau. They were also the keepers of bullock carts. In addition to being traders, they hired carts to other traders and merchants. Their lifestyle was mostly

Laxman D. Satya, Department of History, Lock Haven University, Lock Haven, Pennsylvania 17745, USA.

The Journal of Peasant Studies, Vol.24, No.4, July 1997, pp.314-336

PUBLISHED BY FRANK CASS, LONDON 